\title{
EKSISTENSI HARTA DALAM ISLAM (Suatu Kajian Analisis Teoritis)
}

\author{
Rizal \\ APII Kudus, Jawa Tengah, Indonesia \\ Rizal57@yahoo.com
}

\begin{abstract}
THE EXISTENCE OF PROPERTY IN ISLAM (A Study of Theoretical Analysis). Humans have a natural tendency trying to take control and own property as much as possible. In a hadith of the Prophet, explained that the man was not satisfied with his wealth despite a valley-shaped gold so that he died. In fact, al-Quran and alSunnah forcefully argued that the property should not move from one person to another, but in a way that justified by syarak namely through trades or transactions based on consensual. The use of property in Islam should always be in the service of God and utilized in order taqarrub (closer) to Allah. Utilization of personal property must not only for the owner's personal possessions, but also used for social functions in order to help fellow buman beings. Islam has given special attention to the property in terms of both how to obtain and use that property owned it has a value of worship with Allah in order to achieve a happier life in the hereafter. A Muslim is commanded to make a living and generate wealth by striving mightily. Islam has given special attention to the property in terms of both ways. How actually the concept of property in Islam, then the following study will explain it.
\end{abstract}

Keywords: Hidden Existence, Ownership, Happiness. 


\begin{abstract}
Abstrak
Manusia memiliki fitrah berupaya untuk menguasai dan memiliki harta sebanyak mungkin. Dalam sebuah hadith Rasulullah saw., dijelaskan bahwa manusia itu tidak akan puas dengan bartanya walaupun berbentuk satu lembah emas sehingga dia mati. Malahan al-Quran dan al-Sunnah dengan tegas menjelaskan babwa harta tidak boleb berpindah milik dari seorang kepada orang yang lain melainkan dengan cara yang dibenarkan oleh syarak yaitu melalu perdagangan atau transaksi yang didasari atas suka sama suka. Penggunaan harta dalam ajaran Islam harus senantiasa dalam pengabdian kepada Allah dan dimanfaatkan dalam rangka taqarrub (mendekatkan diri) kepada Allah. Pemanfaatan harta pribadi tidak boleb hanya untuk pribadi pemilik harta, melainkan juga digunakan untuk fungsi sosial dalam rangka membantu sesama manusia. Islam telah memberikan perhatian khusus terhadap harta baik dari segi cara mendapatkannya maupun penggunaannya sehingga harta yang dimiliki itu mempunyai nilai ibadah di sisi Allah dalam rangka pencapaian kehidupan yang lebih bahagia di akhirat. Seorang Muslim diperintabkan untuk mencari nafkah dan menghasilkan harta dengan berjuang sekuat tenaga. Islam telah memberikan perhatian khusus terhadap harta baik dari segi cara Bagaimanakah sebetulnya konsep harta dalam Islam, maka kajian berikut akan menjelaskannya.
\end{abstract}

Kata kunci: Eksistensi Harta, Kepemilikan, kebahagiaan.

\title{
A. Pendahuluan
}

Islam mempunyai konsep tersendiri terhadap harta (mal) yang berbeda dengan konsep harta menurut perspektif sivil. Harta (mal) dari segi bahasa disebut dengan al-mal yang berasal dari kata ((يميل - ميلا yang berarti condong, cenderung dan miring. ${ }^{.}$Nasrun Haroen dengan ungkapan yang agak berbeda mengungkapan bahwa al-mal berasal dari kata mala yang berarti condong atau berpaling dari tengah ke salah satu sisi dan al-mal diartikan sebagai segala sesuatu yang menyenangkan manusia dan mereka pelihara baik dalam bentuk materi maupun dalam bentuk manfaat. ${ }^{2}$ Menurut al-

\footnotetext{
${ }^{1}$ Hendi Suhendi. Fiqh Muamalah (Jakarta: Rajawali Press, 2005), hlm. 9.

${ }^{2}$ Nasrun Haroen, Fiqh Muamalah (Jakarta: Gaya Media Pratama, 2000), hlm. 73 .
} 
Qamus al-Muhit al-mal ialah sesuatu yang boleh dimiliki. ${ }^{3}$ Menurut Wahbah al-Zuhayli harta dari segi bahasa ialah setiap barang yang benar-benar dimiliki dan dikuasai (biyazah) oleh seseorang, baik dalam bentuk 'ain ataupun manfaat. Contoh harta 'ain adalah emas, perak, binatang, dan tumbuh-tumbuhan. Sedangkan contoh harta manfaat adalah seperti menunggang kendaraan, memakai pakaian dan mendiami rumah. Barang yang tidak dikuasai oleh seseorang, tidak dinamakan harta dari segi bahasa. Umpamanya burung di udara, ikan di dalam air, pohon di hutan dan galian di perut bumi. ${ }^{4}$

\section{B. Pembahasan}

Para fuqaha' memberikan berbagai definisi tentang harta. Sebagian dari mereka mendefinisikan harta sebagai sesuatu yang diingini oleh tabiat manusia dan boleh disimpan untuk tempoh yang diperlukan atau sesuatu yang dapat dikuasai, disimpan dan dimanfaatkan. ${ }^{5}$ Muhammad Salam Madkur menungkapkan bahwa harta menurut para ulama figh ialah segala sesuatu yang boleh dikuasai dan disimpan untuk dipergunakan kapan diperlukan. AlSyarbaini al-Khatib berpendapat, harta adalah sesuatu yang ada nilai dan orang yang merusakkannya akan diwajibkan membayar ganti rugi. Menurut golongan Hanafi, harta merupakan benda atau barang yang boleh dikuasai dan kebiasaannya boleh diambil faedah darinya. ${ }^{6}$ Maksudnya ialah sesuatu harta itu perlu ada dua unsur yaitu: ${ }^{7}$

Pertama, boleh dikuasai (biyazab). Oleh karena itu, sesuatu barang yang tidak bisa dikuasai, tidak dianggap harta. Jadi perkaraperkara maknawi seperti pengetahuan, kesihatan, kemuliaan dan kecerdikan tidaklah dianggap harta sebab ia tidak boleh dikuasai. hlm. 53 .

${ }^{3}$ Al-Fairuz Abadi. t.th, Al-Qamus al-Mubit, Juz. 4. (Beirut: Dar al-Jail.t.t),

${ }^{4}$ Wahbah al-Zuhayli. M, Al-Fiqh al-Islam wa Adilatubu, Jil. 4 (Damsyik: Dar al-Fikr: 1425 H/2004), hlm. 40.

${ }^{5}$ Ibn Abidin, Hasyiah Rad al-Mukhtar ala al-Dar al-Mukbtar Sharb Tanwir al-Absar, Jil. 4 (Mesir: Matbaah Mustafa al-Halabi: 1966), hlm. 501.

${ }^{6}$ Al-Syarbaini al-Khatib, Mughnii al-Mubtaj, Jil. 4 (Beirut: Dar al-Fikr. 1978), hlm. 246.

${ }^{7}$ Ibid., 40). 
Demikian juga dengan sesuatu yang tidak boleh dikuasai seperti udara bebas, panas matahari dan cahaya bulan. Kedua, Pada kebiasaannya boleh diambil faedah. Oleh karena itu, sesuatu yang langsung tidak boleh diambil faedah darinya seperti daging bangkai, makanan yang beracun, makanan yang sudah rusak ataupun sesuatu yang boleh diambil manfaat darinya, tetapi tidak dianggap manfaat oleh manusia, pada kebiasaannya seperti sebiji gandum atau setitik air, maka ia tidak dianggap harta karena ia tidak bermanfaat apabila terpisah dari kesatuan yang lainnya.

Berasaskan definisi para fuqaha' di atas dapat dijelaskan bahwa menurut fuqaha' selain dari Hanafi mengungkapkan harta itu tidak saja bersifat materi, tetapi juga termasuk manfaat dari sesuatu benda sebab ia boleh diambil dan dikuasai dengan cara mengambil asal dan sumbernya. Juga karena manfaat dan hak-hak itu menjadi tujuan dari sesuatu benda (barang), jika tidak ada manfaat, maka benda-benda itu tidak akan diambil (dicari) dan orang tidak akan menyukainya. Sedangkan fuqaha' dari golongan Hanafi membatasi definisi harta pada perkara-perkara atau benda-benda yang mempunyai pisik dan zat yang dapat dirasa. Adapun mengenai manfaat dan hak-hak, maka itu tidak dihitung harta pada pandangan mereka, ia merupakan milik tetapi bukan harta.

Ulama Hanafi Mutaakhirin berpendapat bahwa definisi al-mal yang dikemukakan oleh pendahulunya dianggap tidak komprehensif dan kurang akomodatif sehingga mereka lebih cenderung untuk menggunakan definisi al-mal yang dikemukakan oleh jumhur ulama di atas, karena persoalan al-mal terkait dengan persoalan adat kebiasaan, situasi dan kondisi suatu masyarakat. Menurut mereka, kondisi hari ini kadangkala manfaat sesuatu benda boleh banyak menghasilkan penambahan harta dibandingkan pisik bendanya sendiri, seperti perbandingan harga antara mengontrakkan rumah selama beberapa tahun dari menjualnya. Oleh karena itu, Mustafa Ahmad al-Zarqa' dari golongan Hanafi Mutaakhirin mengungkapkan 
definisi al-mal sebagai sesuatu yang mempunyai nilai materi di kalangan masyarakat. ${ }^{8}$

Berasaskan perubahan definisi yang diungkapkan oleh Mustafa Ahmad al-Zarqa di atas, secara keseluruhan baik definisi yang dikemukakan oleh jumhur ulama atau golongan Hanafi Mutaakhirin, maka dapat dibuat kesimpulan bahwa segala sesuatu itu boleh disebut sebagai harta apabila memenuhi dua syarat berikut: Pertama, benda itu boleh dimiliki. Kedua, benda itu boleh dimanfaatkan.

Berikut ini ada beberapa perkara yang bisa masuk ke dalam ciri-ciri harta yaitu:

a. Sesuatu yang kita miliki dan boleh diambil manfaat darinya seperti rumah, kereta, tanah dan sebagainya.

b. Sesuatu benda yang belum kita miliki, tetapi berkemungkinan untuk memilikinya juga dianggap sebagai harta. Karena ia dapat dimiliki, seperti ikan di laut, burung di udara atau binatang di hutan boleh dianggap sebagai harta. ${ }^{9}$

c. Sesuatu yang tidak boleh dimiliki walaupun boleh dimanfaatkan seperti udara, cahaya dan sebagainya, tidak dianggap sebagai harta.

d. Sesuatu yang tidak dapat dimanfaatkan dalam keadaan biasa seperti setitik air atau sebiji beras, walaupun boleh dimiliki, tidak dianggap sebagai harta. Maksud kegunaan dalam keadaan biasa ialah kegunaan mengikut kebiasaan manusia dan tabiat sesuatu benda tersebut. Beras, sebagai contohnya adalah makanan manusia yang mengenyangkan sebaliknya jika sebiji saja, beras tidak lagi sebagai sesuatu yang memberi manfaat kepada manusia walaupun boleh disimpan dan dimiliki.

e. Sesuatu yang dicegah oleh syara' untuk dimanfaatkan oleh semua orang, tidak dianggap sebagai harta walaupun

\footnotetext{
${ }^{8}$ Mustafa Ahmad al-Zarqa' (1999: 127)

${ }^{9}$ Faizah Ismail, Asas Muamalat dalam Islam (Kuala Lumpur: Dewan B hasa dan Pustaka, 1995), hlm. 65.
} 
benda itu dapat dimiliki dan dimanfaatkan oleh seseorang. Contoh seperti bangkai yang dicegah oleh syara' untuk dimanfaatkan. ${ }^{10}$

f. Seandainya sesuatu itu diharuskan boleh dimanfaatkan oleh sebagian golongan manusia, ia masih dianggap sebagai harta bagi mereka seperti babi dan arak, yaitu dianggap harta bagi kafir dhimmi tetapi tidak bagi orang Islam. Karena orang-orang Islam tidak boleh mengambil manfaat dari arak dan babi kecuali dalam keadaan darurat yang telah memenuhi syarat-syaratnya. Begitu juga, kedua-duanya tidak boleh dijadikan hak milik. Harta jenis ini dikenal sebagai harta yang tidak bernilai pada pandangan syara'. Walau bagaimanapun, Imam Abu Hanifah menganggap bahwa arak dan babi merupakan harta yang bernilai bagi orang-orang bukan Islam. Sebaliknya, jumhur ulama' secara mutlak tidak menganggap kedua-duanya sebagai harta yang bernilai walaupun kepada bukan Islam. ${ }^{11}$

\section{Kedudukan dan Fungsi Harta}

Seperti yang telah diuraikan sebelumnya bahwa sesuatu dinamakan harta manakala ia boleh dimiliki dan dimanfaatkan. Harta termasuk salah satu keperluan pokok manusia dalam menjalani kehidupan di dunia ini, sehingga oleh para ulama ushul fiqh persoalan harta dimasukan ke dalam salah satu al-daruria alkhamsah (lima keperluan pokok), yang terdiri ke atas agama, jiwa, akal, keturunan dan harta. ${ }^{12}$ Oleh karena itu, mempertahankan harta dari segala upaya yang dilakukan orang lain dengan cara yang tidak sah, termasuk di dalam kelompok yang penting dalam Islam. Dalam hal ini, misalnya, Allah menentukan hukuman potong tangan bagi pencuri seperti yang tertuang dalam firman Allah dalam Al-Qura'an, surat al-Maidah 5:38 sebagai berikut:

${ }^{10}$ Ibid., hlm. 2-3

${ }^{11}$ Ibid., hlm. 43.

${ }^{12}$ Abu Ishaq al-Shatibi, Al-Muawafaqat fi Ushul al-Syariah. Jil. 2, (Beirut: Dar al-Ma'rifah, 1973), hlm. 8. 


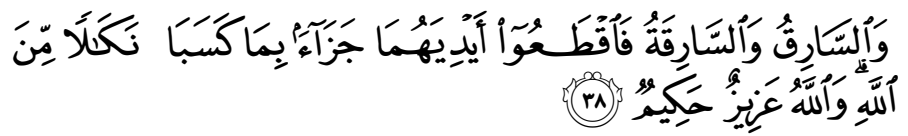

"laki-laki yang mencuri dan perempuan yang mencuri, potonglah tangan keduanya (sebagai) pembalasan bagi apa yang mereka kerjakan dan sebagai siksaan dari Allah. dan Allah Maha Perkasa lagi Maha Bijaksana."

Hukuman bagi pencuri yang ditentukan Allah ini tidak lain adalah sebagai bentuk pemeliharaan dan penghormatan Islam atas harta seseorang. Namun demikian, sekalipun seseorang diberi harta oleh Allah, orang tersebut tidak boleh berlaku sewenangwenang dalam menggunakan hartanya itu. Kebebasan seseorang untuk memanfaatkan hartanya adalah sebatas yang dibolehkan oleh syara'. Oleh sebab itu, dalam penggunaan harta, di samping untuk kemaslahatan pribadi pemilik harta, harus dapat juga memberikan manfaat dan kemaslahatan untuk orang lain.

Penggunaan harta dalam ajaran Islam harus senantiasa dalam pengabdian kepada Allah dan dimanfaatkan dalam rangka taqarrub (mendekatkan diri) kepada Allah. Pemanfaatan harta pribadi tidak boleh hanya untuk pribadi pemilik harta, melainkan juga digunakan untuk fungsi sosial dalam rangka membantu sesama manusia. ${ }^{13}$ Dalam kaitan ini Rasulullah bersabda:

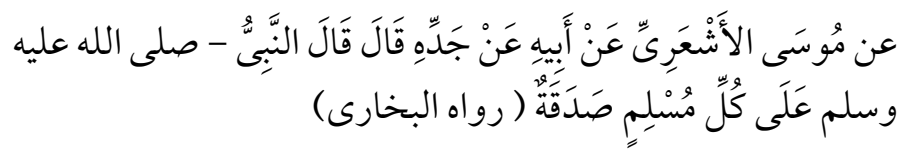

'Dari Musa al-'Asy'ari dari bapaknya, dari kakeknya, ia berkata. Nabi s.a.w. bersabda babwa kewajiban bagi setiap orang Muslim untuk bersedekah." (HR. al-Bukhari). (Maktabah al-Samilah: Sahih al-Bukhari Juz. 20: hal. 139).

Hadith ini menunjukkan bahwa dalam harta seseorang terdapat hak orang lain. Inilah yang disebut dengan hak masyarakat yang berfungsi sosial untuk kesejahteraan sesama manusia. Di samping itu, Rasulullah s.a.w. juga melarang membuang-buang harta seperti yang tertuang dalam sabdanya:

\footnotetext{
${ }^{13}$ Nasrun Haroen, Fiqh Muamalah (Jakarta: Gaya Media Pratama, 2000),
} hlm. 76 . 


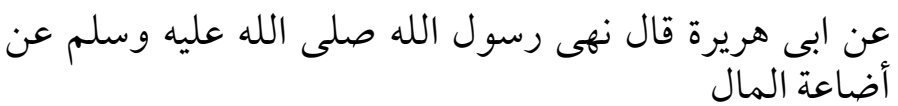

"Rasulullah s.a.w. melarang membuang-buang harta." (HR. al-Bukhari). (Maktabah al-Samilah: Sahih al-Bukhari Juz. 5: hal. 392).

Sabda Rasul ini mengandung pengertian bahwa sekalipun seseorang telah memiliki harta yang berlimpah, tidak boleh ia membuang hartanya secara percuma, karena di dalam hartanya itu terkait dan terdapat hak-hak orang lain yang memerlukannya. Dalam kaitan ini, seseorang yang secara mubazir menggunakan hartanya, menurut para ulama fiqh, berhak ditetapkan sebagai seseorang yang berada di bawah penahanan (al-hajr). ${ }^{14}$

Dari uraian di atas terlihatlah bahwa Islam telah memberikan perhatian khusus terhadap harta baik dari segi cara mendapatkannya maupun penggunaannya sehingga harta yang dimiliki itu mempunyai nilai ibadah di sisi Allah dalam rangka pencapaian kehidupan yang lebih bahagia di akhirat. Seorang Muslim diperintahkan untuk mencari nafkah dan menghasilkan harta dengan berjuang sekuat tenaga. Tangan yang memberikan bantuan, dalam pandangan Islam jauh lebih baik dari tangan yang menerima kucuran bantuan sebagaimana yang dikemukakan dalam sebuah hadith Rasulullah saw:

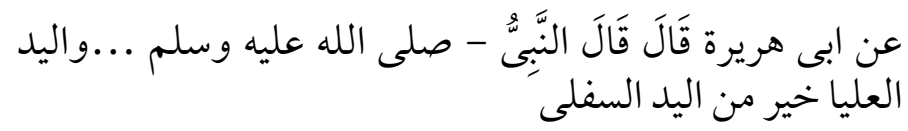

"Dari Abi Hurairah ra. Ia berkata, Rasulullah saw., bersabda tangan yang di atas lebih baik dari tangan yang di bawab". (HR. al-Bukhari). (Maktabah al-Samilah: Sahih al-Bukhari Juz. 18: hal. 64).

Harta tidak saja berkedudukan untuk mendekatkan diri kepada Allah tetapi harta juga berfungsi dalam kehidupan ini. Antara fungsi harta tersebut adalah:

${ }^{14}$ Fatih Duraini, Al-Haqq ma Mada Sultán al-Daulah fi Taqyidibi (Beirut: Mu'assasah al-Risalah, 1977), hlm. 231. 
1) Harta merupakan amanah (titipan, as a trust) dari Allah SWT. Manusia hanyalah pemegang amanah karena memang tidak mampu mewujudkan harta dari tiada.

2) Harta berfungsi sebagai perhiasan hidup yang memungkinkan manusia boleh menikmatinya dengan baik dan tidak berlebih-lebihan. Manusia memiliki kecenderungan yang kuat untuk memiliki, menguasai dan menikmati harta. Hal ini selari dengan firman Allah dalam Al-Qur'an, surat Ali Imran ayat 14:

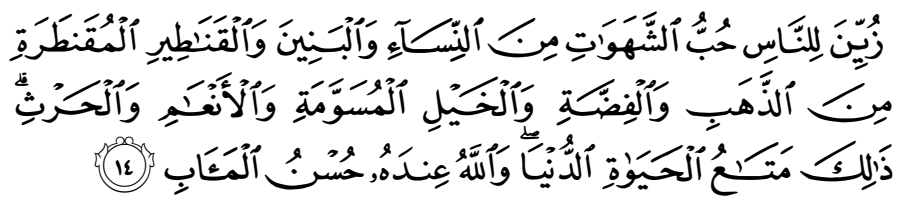

"Dibiaskan kepada manusia, mencitai syabwat (keinginan nafsu), seperti perempuan-perempuan, anak-anak dan barta benda yang banyak dari emas, perak, kuda yang baik, binatang-binatang ternak dan tanam-tanaman. Demikianlab kesukaan bidup dunia dan di sisi Allah tempat kembali yang sebaik-baiknya (yaitu surga).

Namun, terkait dengan fungsi harta sebagai perhiasan dalam kehidupan manusia, seringkali manusia terlupa akan kedudukan harta untuk mendekatkan diri semata kepada Allah. Sehingga sering harta ini membuat manusia menjadi sombong dan berbangga diri sehingga lupa kepada Allah sebagai pemberi harta tersebut.

3) Harta sebagai ujian keimanan. ${ }^{15} \mathrm{Hal}$ ini terutama menyangkut tentang cara mendapatkan dan memanfaatkannya, apakah sesuai dengan ajaran Islam atau tidak. Hal ini sesuai dengan firman Allah dalam Qur'an, surat al-Anfal, 8: 28:

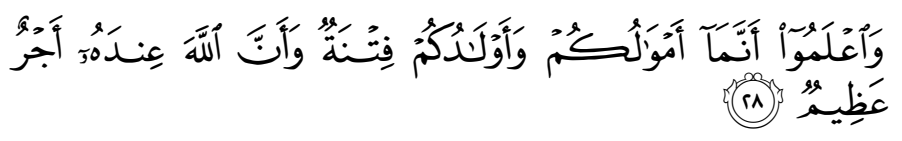

"Dan ketabuilah, bahwa harta dan anak-anakmu menjadi fitnah (ujian) dan sesunggubnya di sisi Allab pabala yang besar."

${ }^{15}$ Muhammad Syafii Antonio, Bank Syariah dari Teori ke Praktek (Jakarta: Gema Insani, 2001), hlm. 9. 
Begitu juga dengan memiliki harta orang akan dapat senang beribadah kepada Allah. Sebaliknya bila orang tidak memiliki harta, maka hal itu bisa menjadi sebab jauhnya dari Allah karena kefakiran cenderung mendekatkan diri kepada kekufuran sehingga orang yang memiliki harta akan dapat membantu dirinya untuk menegakkan ketaqwaan kepada Allah. Di samping itu, untuk lengkapnya rukun Islam dalam diri hamba mestilah ia memiliki harta. Bila tidak tentulah ia tidak akan bisa membayarkan zakat dan menunaikan ibadah haji.

4) Harta sebagai bekal ibadah, yakni untuk melaksanakan perintah-Nya dan melaksanakan muamalah di antara sesama manusia, melalui kegiatan zakat, infak dan sedekah. Hal ini selari dengan firman Allah dalam Qur'an, surat alTaubah ayat 41:

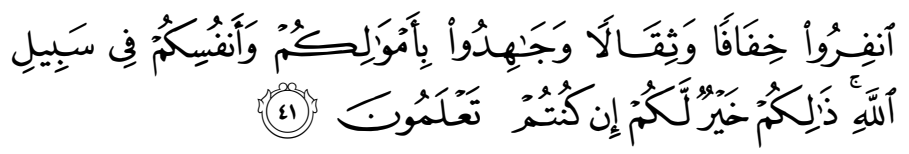

"Keluarlah kamu (ke medan pertempuran) dengan berjalan kaki atau berkendaraan dan berjuanglab dengan harta dan dirimu di jalan Allah. Demikian itu lebih baik bagimu."

5) Harta berfungsi juga untuk meneruskan kehidupan dari satu generasi ke generasi berikutnya, ${ }^{16}$ seperti yang tertulis dalam firman Allah dalam Qur'an, surat al-Nisa' ayat 9:

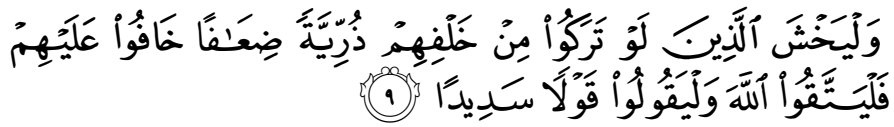

"Dan hendaklah mereka takut jika sekiranya mereka meninggalkan anakanak yang masih lemah di belakangnya, takut akan terlantar anak-anak. itu, maka hendaklah mereka takut kepada Allah dan berkatalah dengan perkataan yang betul."

Dari uraian di atas, seharusnyalah harta itu diperoleh melalui cara halal yang telah diatur secara jelas di berbagai ayat-

${ }^{16}$ Hendi Suhendi., Figh Muamalah, hlm.28. 
ayat dalam Al Quran dan Hadist Rasullulah s.a.w. Demikian pula dalam menggunakan atau membelanjakan harta harus pula dengan cara yang baik demi memperoleh ridho Allah SWT serta tercapainya distribusi kekayaan yang adil di tengah-tengah masyarakat. Penggunaan atau pembelanjaan harta wajib dibatasi pada sesuatu yang halal dan sesuai Syariah. Dengan demikian, harta itu jangan sampai digunakan untuk perjudian, membeli minuman keras dan barang-barang yang diharamkan, membayar perzinahan, atau apa saja yang dilarang oleh Syariah.

\section{Pembagian Harta}

Ahli-ahli fiqh membagikan harta kepada beberapa bagian, tiap-tiap bagian memiliki ciri-ciri tersendiri dan mempunyai ketentuan hukum yang berbeda menurut bagian masing-masing. Namun demikian, memadailah menyebutkan beberapa bagian saja. Bagian-bagian tersebut adalah:

Pertama dilihat dari segi kebolehan pemanfaatannya menurut syara', harta itu dapat dibagi kepada harta bernilai (al-mal almutaqawnim) dan tidak bernilai (al-mal ghair al-mutaqawnim). Harta bernilai (al-mal al-mutaqawwim), ialah harta yang dimiliki dan syara' membolehkan penggunaannya. Ibn Abidin mendefiniskan bahwa almal al-mutaqawwim ialah harta yang diakui kepemilikannya oleh syarak bagi pemiliknya. ${ }^{17}$ Pengakuan syarak ini hanya akan berlaku dengan adanya syarat-syarat yang berikut: (a) harta tersebut dimiliki oleh pemilik berkenaan secara sah. (b) harta tersebut boleh dimanfaatkan mengikut hukum syarak dalam keadaan biasa. ${ }^{18}$ Seperti harta-harta tidak bergerak, harta bergerak, makanan dan sebagainya. Sedangkan harta yang tidak bernilai (al-mal ghair al-mutaqawwim), ialah sesuatu yang tidak dimiliki, atau sesuatu yang syara' tidak membolehkan penggunaannya kecuali ketika darurat (terpaksa). ${ }^{19}$

${ }^{17}$ Ibn Abidin, Hasyiah Rad al-Mukhtar ala al-Dar al-Mukhtar Sharb Tanwir al-Absar, Jil. 4 (Mesir: Matbaah Mustafa al-Halabi: 1966), hlm. 501.

${ }^{18}$ Faizah Ismail, Asas Muamalat dalam Islam, hlm. 475.

${ }^{19}$ Al-Syarbaini al-Khatib, Mughnii al-Mubtaj, hlm. 7. 
Dalam ungkapan lain al-mal ghair al-mutaqawnim merupakan harta yang tidak dibolehkan penggunaannya oleh syara'. ${ }^{20}$ Munurut Muhammad Salam Madkur termasuk ke dalam jenis harta ini adalah sesuatu yang sudah dimiliki zat nya tetapi syarak melarang memanfaatkannya seperti arak dan babi. ${ }^{21}$ Demikian pula, jika harta tersebut belum dimiliki dengan sebenarnya seperti ikan yang masih berada dalam sungai atau burung yang masih di udara maupun penggunaannya tidak dibenarkan oleh syara' dalam keadaan biasa, seperti arak atau daging babi bagi orang Islam, atau begi semua orang. mengikut pendapat setengah fuqaha' seperti Imam Abu Hanifah dan Ibn Hazm al-Zahiri. ${ }^{22}$ Tujuan pengkategorian ini dibuat dapat dilihat dalam masalah-masalah berikut:

Dalam masalah akad atau kontrak. Sah atau tidaknya mengadakan kontrak terhadap harta tersebut. Dalam hal ini, harta yang sah dibuat semua jenis kontrak kepadanya seperti kontrak jual, beli, sewa, hibah, pinjam, gadai, wasiat, syarikat dan sebagainya. Harta tidak bernilai, tidak sah diadakan apa saja kontrak harta ke atasnya. Oleh karena itu, penjualan arak atau babi oleh orang Islam adalah dihitung batal. Jika orang Islam membeli arak atau babi, maka pembelian itu adalah fasid. Sebab perbedaan di antara dua keadaan itu ialah barang yang dijual itu adalah menjadi tujuan dari jual beli. Oleh karena itu, bernilainya barang jualan itu adalah menjadi syarat berlaku kontrak (shart in 'iqad). Adapun harga maka ia hanya wasilah (perantara) yang tidak dimaksud zatnya. Oleh karena itu, bernilainya harga itu adalah menjadi syarat sah. ${ }^{23}$

Dalam masalah pembayaran ganti rugi. Jika seseorang merusakkan harta bernilai kepunyaan orang lain maka dia wajib membayar ganti ruginya jika barang (harta) itu adalah harta mithli.

${ }^{20}$ Ibid., hlm. 502.

${ }^{21}$ Muhammad Salam Madkur, M, Al-Madkhal li al-Figh al-Islami:Tarikhubu wa Mashadirubu wa Narriyatubu al-Amma (Kahirah: Dar al-Nahdah al-Arabi, 1963), hlm. 476.

${ }^{22}$ Ibn Qudamah,. al-Mughni. Jil. 4 (Kahirah: Matbaah al-Manar.: 1348 H), hlm.147.

${ }^{23}$ Wahbah al-Zuhayli, 2004 M, Al-Fiqh al-Islam wa Adilatubu, hlm. 44-45. 
Begitu juga, ia wajib mengganti nilainya, apabila barang (harta) itu merupakan harta qimiy. Adapun harta yang tidak berharga, maka kerusakannya tidak perlu dibayar ganti rugi sekiranya barang itu dimiliki oleh orang Islam. Oleh karena itu, jika seorang menuangkan arak kepunyaan orang Muslim ke tanah atau membunuh babi kepunyaannya, maka ia tidak perlu membayar ganti rugi. Akan tetapi, jika seseorang memusnahkan arak atau babi kepunyaan seorang dhimmi (orang yang bukan Islam mendiami negara Islam), maka dia mestilah membayar ganti rugi harganya pada pandangan golongan Hanafi, karena itu merupakan harta bernilai pada mereka. ${ }^{24}$ Akan tetapi, menurut Jumhur Ulama bahwa dalam masalah seorang Muslim merusak atau menghancurkan babi atau arak kepunyaan seorang dhimmi tidak boleh dituntut ganti rugi, kerana kedua jenis benda tersebut tidak bernilai harta dalam Islam. ${ }^{25}$

Kedua, dilihat dari sifat harta itu sendiri, maka harta boleh dibagi kepada harta tidak bergerak dan harta bergerak. Harta tidak bergerak ('aqâr) ialah harta yang kekal di tempatnya yang tidak boleh dipindah dan diubah sama sekali ke tempat lain. ${ }^{26}$ Muhammad Salam Madkur mengemukakan bahwa definisi harta tidak bergerak menurut al-Malikiyah ialah segala sesuatu yang kekal di tempatnya tidak boleh diubah atau dipindah tempat dari satu temapat ke tempat yang lain serta bentuk dan strukturnya tetap tidak berubah. Sedangkan harta bergerak (al-manqu) ialah harta yang boleh dipindah dan diubah dari satu tempat ke satu tempat yang lain. ${ }^{27}$ Apakah bentuk dan strukturnya tetap atau bertukar karena perpindahan itu. Harta bergerak ini termasuklah uang, barang perniagaan, binatang, barang sukatan dan timbangan. ${ }^{28}$

\footnotetext{
${ }^{24}$ Ibid., 45

${ }^{25}$ Mustafa Ahmad al-Zarqa', Al-Madkhal ila Nazriyat al-Iltizam al-Ammah fi al-Fiqh al-Islam (Damsiq: Dar al-Qalam. 1999). Hlm. 126-127.

${ }^{26}$ Ibid., 46.

${ }^{27}$ Muhammad Salam Madkur, M, Al-Madkhal li al-Figh al-Islami: Tari bubu wa Mashadirubu wa Nazriyatubu al-Amma (Kahirah: Dar al-Nahdah al-Arabi, 1963), hlm. 478.

${ }^{28}$ Wahbah al-Zuhayli, Al-Figh al-Islam wa Adilatubu, hlm. 44-45
} 
Dalam masalah ini Imam Malik mempunyai pandangan yang agak berbeda dengan pandangan para fuqaha' lain. Dia berpendapat, harta bergerak ialah sesuatu yang boleh dipindah dari satu tempat ke satu tempat lain tanpa merusakan atau mengubah bentuk dan sifat asal benda itu sendiri. Tetapi, jika perpindahan itu menyebabkan benda itu berubah bentuk dan sifat asalnya, harta itu dinamakan harta tidak bergerak.

Akibat hukum dari perbedaan harta dari segi sifatnya ini adalah sebagai berikut:

a. Berlakunya hak syuf'ah (hak istimewa yang dimiliki seseorang ke atas rumah jirannya yang akan dijual, agar rumah itu terlebih dahulu ditawarkan kepadanya). Ini berlaku bagi harta tidak bergerak. Akan tetapi, jika harta itu bergerak, maka tidak tetap syuf'ah, sekira ia dijual berasingan dengan dari 'aqar. ${ }^{29}$

b. Dalam masalah wakaf, menurut ulama Hanafiyah, hanya benda tidak bergerak yang boleh diwakafkan. Mewakafkan harta bergerak tidak dibolehkan kecuali harta bergerak itu mengikuti sesuatu yang 'aqar. Akan tetapi, Jumhur ulama berpendapat bahwa kedua-dua benda tersebut boleh diwakafkan. ${ }^{30}$

c. Dalam penjualan harta orang yang cacat pikiran oleh wâsi. Wâsi tidak boleh menjualkan sesuatu harta 'aqar (harta tidak bergerak) yang dimiliki oleh orang yang cacat pikiran kecuali dengan alasan-alasan yang dibenarkan oleh syara' seperti untuk membayar hutang, menyempurnakan sesuatu keperluan yang mendesak ataupun untuk sesuatu yang nyata maslahatnya. Akan tetapi, mengenai harta bergerak wâsi boleh menjualnya kapan saja jika dia mendapati ada maslahat untuk berbuat demikian.

d. Berlainan dengan ahli-ahli fiqh yang lain. Abu Hanifah dan Abu Yusuf membenarkan penjualan 'aqar sebelum diterima

\footnotetext{
${ }^{29}$ Nasrun Haroen, Figh Muamalah., hlm. 254.

${ }^{30}$ Ibid., hlm. 46
} 
dari pembeli. Harta manqul tidak boleh dijual sebelum diterima atau diserah. Ini karena harta manqul lebih banyak berpotensi untuk rusak. Sedangkan harta 'aqar tidak banyak berlaku sedemikian. ${ }^{31}$

e. Hak kejiranan (jiwar) dan hak penggunaan (irtifaq) hanya ada pada harta 'aqar. Hak ini tidak ada pada harta manqul.

f. Abu Hanifah dan Abu Yusuf mengatakan bahwa mustahil 'aqar boleh dirampas, sebab ia tidak boleh dipindahkan. Sedangkan Muhammad dan ahli fiqh yang lain mengatakan tidak mustahil. ${ }^{32}$

Ketiga, dilihat dari segi pemanfaatannya, harta dapat dibagi kepada harta al-isti'mali dan harta al-istiblaki. Harta al-isti'mali ialah harta yang apabila digunakan atau dimanfaatkan benda itu kekal zatnya (tidak habis), sekalipun manfaatnya sudah banyak digunakan. Contoh harta al-isti'mali ialah lahan pertanian, rumah, dan buku. Sedangkan harta al-istiblaki ialah harta yang apabila dimanfaatkan berakibat habisnya harta itu. Contohnya ialah sabun, pakaian, dan makanan. Hukum dari perbedaan harta ini menurut ulama figh hanya dari segi akadnya saja. Untuk harta yang al-istiblaki, akadnya hanya tolong menolong, seperti meminjam sabun, pakaian, dan meminta makanan. Sedangkan harta al-isti'mali, di samping sifatnya tolong menolong, juga boleh ditransaksikan dengan cara mengambil pulangan, seperti al-ijarah (sewa-menyewa).

Keempat, Harta serupa (mithliy) dan harta senilai (qimiy). Pembagian ini dibuat berdasarkan harta tersebut ada yang serupa dengannya atau sebaliknya. Yang dimaksud dengan harta serupa ialah harta yang mempunyai persamaan dengan harta lain di pasaran, sama dari segi bentuk atau nilai. Jika ada perbedaan antara kedua-dua harta tersebut, perbedaan itu dalam kadar yang boleh diterima oleh semua pihak. ${ }^{33}$

\footnotetext{
${ }^{31}$ Wahbah al-Zuhayli, Al-Figh al-Islam wa Adilatubu, hlm. 48

${ }^{32}$ Ibid., 49.

${ }^{33}$ Abdul Karim Zaidan, Al-Madkhal li Dirasah al-Syariah al-Islamiyah (I -
} 
Harta yang dimaksudkan ialah yang dinilai berdasarkan sukatan, timbangan atau bilangan. Sedangkan yang dimaksudkan dengan harta senilai ialah harta yang tidak ada jenis yang sama dengannya di pasaran atau terdapat jenis yang sama tetapi berbeda dari segi nilai dan harga dengan kentara dan tidak boleh diterima oleh semua pihak baik pembeli maupun penjual. ${ }^{34}$ Kadangkala, harta yang serupa boleh bertukar menjadi harta senilai. Misalnya harta tersebut merupakan hasil pembuatan yang tidak lagi dikeluarkan oleh pengeluarnya, seperti kereta, yaitu pengeluarnya sudah tidak lagi mengeluarkan jenis itu untuk pasaran.

Menurut Wahbah al-Zuhayli, pertukaran harta mithliy menjadi harta qimiy bisa terjadi dalam empat keadaan:

a. Tidak ada stok di pasar. Jika harta mithliy terputus (tidak ada stok) di pasar, maka ia bertukar menjadi harta qimiy.

b. Percampuran. Jika dua harta mithliy yang terdiri dari satu jenis yang berbeda, seperti gandum dan beras, bercampur maka percampuran itu menjadi qimiy.

c. Jika harta mithliy terbakar atau tenggelam, maka harta itu menjadi harta yang bernilai khusus.

d. Cacat atau digunakan. Jika harta mithliy menjadi cacat atau telah digunakan maka ia menjadi harta yang bernilai khusus.

Pertukaran harta qimiy menjadi harta mithli bisa berlaku ketika harta itu pada awalnya sedikit bertukar menjadi banyak. Jika harta itu pada kebiasaannya jarang terdapat di pasar kemudian ia menjadi banyak maka harta itu menjadi harta mithliy. Dengan pertukaran ini harganya tidak khusus lagi.

Kelima, Pembagian lain yang dikemukakan para ulama fiqh tentang harta adalah dari segi kepemilikannya. Ada harta milik pribadi yang pemiliknya bebas memanfaatkan harta itu selama tidak merugikan orang lain. Ada pula harta milik masyarakat

kandariah: Dar Umar Ibn al-Khattab,1969), hlm. 7.

${ }^{34}$ Muhammad Salam Madkur, M, Al-Madkhal li al-Figh al-Islami., hlm. 480. 
umum yang pemanfaatannya untuk semua orang. Harta milik bersama boleh berubah menjadi milik pribadi apabila telah diambil dan dipelihara dengan baik oleh seseorang. Sebaliknya harta pribadi pun boleh berubah menjadi milik bersama. Perubahan kepemilikan dari milik pribadi kepada milik masyarakat bisa melalui hal-hal berikut: (a) kehendak sendiri dari pemiliknya; misalnya seseorang menjadikan hartanya menjadi harta wakaf yang boleh dipergunakan untuk kepentingan masyarakat; (b) kehendak syara', seperti keperluan umat yang mendesak untuk membuat jalan umum di atas tanah milik pribadi. Dalam hal ini pihak penguasa boleh mempergunakan tanah pribadi untuk kepentingan umum.

Para ulama fiqh juga membagi harta milik masyarakat sebagai berikut: (a) harta yang khusus untuk diperuntukkan bagi kemaslahatan bersama, seperti tempat-tempat ibadah, pemakaman, jembatan, jalan umum dan sarana-sarana pendidikan;

(b) harta yang khusus untuk digunakan bagi kepentingan umum, seperti harta wakaf atau harta yang termasuk ke dalam milik negara; (c) harta seseorang yang manfaatnya diperuntukkan bagi kepentingan umum, seperti tanah wakaf yang diwakafkan seseorang untuk diambil hasilnya, serta tanah-tanah negara yang boleh dipergunakan masyarakat.

\section{Simpulan}

Dari bahasan diatas, dapat diktahui bahwa Para ulama figh juga membagi harta milik masyarakat sebagai berikut: (a) harta yang khusus untuk diperuntukkan bagi kemaslahatan bersama, seperti tempat-tempat ibadah, pemakaman, jembatan, jalan umum dan sarana-sarana pendidikan; (b) harta yang khusus untuk digunakan bagi kepentingan umum, seperti harta wakaf atau harta yang termasuk ke dalam milik negara; (c) harta seseorang yang manfaatnya diperuntukkan bagi kepentingan umum, seperti tanah wakaf yang diwakafkan seseorang untuk diambil hasilnya, serta tanah-tanah negara yang boleh dipergunakan masyarakat. 
Dari paparan di atas dapat dipahami bahwa harta tersebut adalah milik Allah yang di amanahkan kepada manusia. Manusia dituntut untuk selalu mempergunakan harta itu sesuai dengan tuntunan dan petunjuk pemiliknya yaitu Allah. Harta tersebut tidak hanya berfungsi untuk memenuhkan kebutuhan manusia (orang kaya) sendiri, tetapi juga menunjukkan betapa orang kaya tersebut juga wajib memperhatikan orang miskin sehingga harta itu berfungsi sosial. 


\section{DAFTAR PUSTAKA}

Zaidan, Abdul Karim, Al-Madkhal li Dirasah al-Syariah al-Islamiyah, Iskandariah: Dar Umar Ibn al-Khattab 1969.

Al-Shatibi, Abu Ishaq, Al-Muawafaqat fi Ushul al-Syari'ah. Jil. 2, Beirut: Dar al-Ma'rifah. 1973.

Al-Bukhari, Sabih al-Bukhari, CDROOM al-Maktabah alShamilah, Cetakan ke-2. Juz 5. t.t.

Al-Fairuz Abadi, Al-Qamus al-Mubit. Juz. 4, Beirut: Dar al-Jail. t.t.

Al-Khatib, Al-Syarbaini, Mughnii al-Mubtaj. Jil. 4, Beirut: Dar alFikr. 1978.

Ismail, Faizah, Asas Muamalat dalam Islam, Kuala Lumpur: Dewan Bahasa dan Pustaka. 1995.

Duraini, Fatih, Al-Haqq ma Mada Sultán al-Daulah fi Taqvidihi, Beirut: Mu'assasah al-Risalah, 1977.

Suhendi, Hendi, Fiqh Muamalah, Yakarta: Rajawali Press, 2005.

Abidin, Ibn. Hasyiah Rad al-Mukhtar'ala al-Dar al-Mukhtar Sharh Tanwir al-Absar. Jil. 4, Mesir: Matbaah Mustafa al-Halabi, 1966.

al-Mughni, Ibn Qudamah, Jil. 4, Kahirah: Matbaah al-Manar, 1348 $\mathrm{H}$.

Madkur. Muhammad Salam M, Al-Madkhal li al-Fiqh al-Islami: Tarikbubu wa Mashadirubu wa Narriyatubu al-Ammah, (Kahirah: Dar al-Nahdah al-Arabi, 1383 H/1963)

Antonio, Muhammad Syafii, Bank Syariah dari Teori ke Praktek. Jakarta: Gema Insani. 2001.

Al-Zarqa', Mustafa Ahmad Al-Madkhal ila Nazriyat al-Iltizam alAmmah fi al-Fiqh al-Islam. Damsiq: Dar al-Qalam, 1999. 
Haroen, Nasrun, Fiqh Muamalah, Jakarta: Gaya Media Pratama. 2000.

Al-Zuhayli, Wahbah, M. Al-Figh al-Islam wa Adilatubu. Jil. 4, Damsyik: Dar al-Fikr. 1425 H/2004. 